\title{
University equipment fund meets with mixed reaction
}

London. Britain's universities, faced with growing difficulty in maintaining their research facilities, have given a cautious, if slightly sceptical, welcome to a scheme announced by the government last week for competitive grants for new equipment.

Under the scheme, which was announced by Ian Lang, the cabinet minister responsible for science and technology, the government is making available a total of $£ 18$ million for two schemes, for equipment costing below and above $£ 250,000$ respectively. In both cases, the government grants will have to be complemented by an equal sum raised from private sources.

All applications will be peer reviewed through the research councils. Furthermore, the topics to which the equipment is related will be judged in terms of the extent to which they coincide with the priorities identified in the recent Technology Foresight exercise.

Ian Taylor, the junior minister for science, said after the announcement that the government had launched the equipment grant scheme in recognition of the problems faced by universities. "This shows what can be done by bringing the two sides of the dual support system together," said Taylor, referring to the UK policy of funding university research through both the Department of Education and Employment and the Office of Science and Technology (OST). "I do not want there to be an ongoing funding difficulty for equipment related to research."

But representatives of the university community, while acknowledging that the new scheme will inevitably be of value, claim that the amount of money involved is far below current requirements. "This is a drop in the ocean compared to the real needs," says Michael Powell of the Committee of Vice Chancellors and Principals.

Powell points out that, coming only three months after an outcry among university scientists caused by the government's decision to impose a major cut in the funds available to the Department of Education for capital funding grants to universities this year, the announcement of the new scheme "looks a bit like a panic measure".

The single largest contributor to the new scheme will be the Higher Education Funding Council for England (HEFCE), which will provide $£ 11.5$ million towards the fund for major items of research equipment costing over $£ 250,000$ (a further $£ 1.5$ million will be provided by HEFCE's Scottish equivalent).

Brian Fender, the chief executive of the funding council, says that he has been able to find the extra funds by a judicious mix of squeezing and slippage in existing programmes. $\mathrm{He}$ adds that the money being

made available to universities will address three separate objectives.

First, it will help "a little" towards meeting the capital investment needs of higher education institutions; secondly, it will be a way of linking universities to the priorities outlined in the Technology Foresight exercise - many of the reports from which, pub-

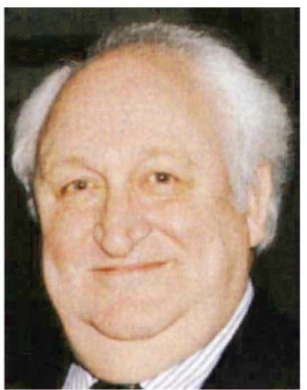

Fender: keen to boost Foresight priorities.

cils and the OST
closer together", a goal already identified in the government's white paper on science published in 1993

But John Mulvey, executive secretary of the pressure group Save British Science, argues that requiring the funding councils to pay most of the costs of large research equipment is "the wrong way round". Mulvey claims that "it is the OST and the research councils which should be putting in this money".

Powell raises a separate criticism, that the government may be being unrealistic in expecting private sources to come up in all cases with the necessary additional funding.

The mixed reactions to the equipment scheme reflect broader ambivalence towards the government budget allocation to science announced last December, the detailed distribution of which was revealed last week. Taylor himself described the decision to raise the science vote by $£ 30$ million, to a total of $£ 1,312$ million, as "a very good settlement in the circumstances".

Such views were reflected in statements from several research councils, welcoming their allocations. The chief executive of the Economic and Social Research Council, Ronald Amann, for example, described his council's total budget of $£ 63$ million as "a very fair one" in what was "a very tight spending round."

In contrast, however, the Medical Research Council, whose budget will fall by 1.5 per cent in real terms next year, declined to offer the OST a pat on the back for its efforts. In a statement, Sir David Plaistow, the council's chairman, emphasized that the cut "will further erode our ability to support long-term internationally competitive British research".

David Dickson

\section{Britain plans to ask for further cuts in CERN running costs}

London. Having successfully led a move last year to secure reductions in the operating costs of the European Space Agency (see Nature 377, 687; 1995), the British government is now turning back to a more familiar protagonist, the European Laboratory for Particle Physics (CERN) in Geneva, Switzerland.

Last week, in announcing how the science budget for the next financial year is to be divided between the six research councils (see left), the Office of Science and Technology pointed out that the whole of the science vote will suffer as a result of a dramatic drop in the value of the pound against the Swiss franc - in which the CERN subscription is paid.

The OST has had to earmark an extra $£ 18$ million above a baseline figure agreed in 1994 to protect the Particle Physics and Astronomy Research Council (PPARC), from whose budget the subscription comes, against the impact of the shifting exchange rate. "We cannot afford increases of this magnitude," says the OST.

The sentiment is echoed by Ken Pounds, chief executive of PPARC, who said in a statement that he supported the government's view that the rate of increase in the UK contribution to CERN had become "unaffordable".

In the light of the concern, government officials say that they intend to pursue discussions with CERN officials to see whether agreement can be reached on reducing the laboratory's operating costs. British attention is focused in particular on the high salaries enjoyed by the fulltime staff of the laboratory. Officials say they accept that the cost of living is high in Switzerland, but point out that many CERN employees live in neighbouring France, where costs are much cheaper.

Last December, Britain joined the German and Italian delegations to the CERN Council in voting against adoption of next year's budget, partly in protest against a new salary award to CERN staff (see Nature 378, 758; 1995). Although failing to secure the numerical majority needed to block the budget, the move was seen as a signal of greater pressure to come.

Taylor is convinced that "there are further efficiency savings which could be made at CERN", while Sir John Cadogan, the director general of research councils, says that last December's vote was "a very good sign" that Britain was unlikely to be alone in seeking a new round of savings, particularly given the rate at which the Swiss franc has appreciated in value against other European currencies. 